\section{Ала Иванчикова}

\section{ФУКО ЗА СMЕEҢЕTО}

\author{
Смеењето е главно привилегија на \\ лудите... \\ (Бодлер, За суштината на \\ смеењето)
}

Вовед

Q овој есеј јас нема да конструирам генерална теорија на смеењето во делата на Фуко. Тоа сепак би било една радикална и предизвикувачка задача, и јас донекаде жалам што ќе морам да ја препуштам на некој друг, посистематичен ум. Сѐ што имам тука да предложам е анализа на неколку епизоди од корпусот на Фукоовите книги, есеи, интервјуа - каде што е присутно смеењето. Ќе се обидам да ја покажам функцијата што ја има смеењето во овие епизоди, без да сугерирам дека оваа функција секаде е иста. Смеењето не е насмевка, каде што во најмала рака може да се забележи нејзината положба - тоа е бестелесен, безличен глас кој не седи на едно место и ни се измолкнува секојпат кога мислиме дека го имаме в раце.

Најверојатно би било корисно да кажам дека овој труд не зборува за хуморот и нема да ве научи како да бидете смешни. Ако читателот тоа го очекувал, веднаш нека прејде на библиографската страна - другите автори ḱe ce погрижат за тоа. Мој предлог е да ги побарате референците за Луис Керол (Lewis Carrol) или Даг Адамс (Doug Adams).

Тука јас се обидувам да се занимавам со прашањето како умот замрзнува некои сеќавања, поточно се-

\section{Alla Ivanchikova}

\section{FOUCAULT ON LAUGHTER}

\author{
Laughter is generally the privilege of \\ the insane... \\ (Baudelaire, On the Essence of Laugh- \\ ter)
}

\section{Introduction}

In my essay I am not going to construct a general theory of laughter in Foucault's works. That would have been a radical and challenging task though, and I slightly regret to have to leave it to some other, more systematic mind. All I have to suggest here is an analytic of several episodes in the body of Foucault's books, essays, interviews, where laughter comes into play. I will try to show the function laughter plays in these episodes without suggesting that this function is necessarily the same. Laughter is not a smile, where at least one could detect its location, - it's a disembodied faceless voice which doesn't stay within its own belongings and tends to traverse them every time we think it's in our hands.

It is probably useful to say that this paper is not about humor and it won't teach one how to be funny. If the reader was expecting to find something like this, she'd better go directly to the bibliography page - other authors will take care of you. Check for Lewis Carrol or Doug Adams references, that would be my suggestion.

Here I was simply trying to deal with the issue of how the mind comes to freeze some memories, precisely memories 
ќавања кои се трауматични. Го користам зборот „замрзнува" како и секој психоаналитички автор - со значење фиксација и/ли заборавање - најчестите начини за справување со трауми. Мојата прва средба со Фуко дефинитивно беше трауматична - шок разоткриен со смеење кое не бев способна ефективно да го артикулирам. Не можев да го појмам текстот кој одбива да го задржи идентитетот, кој не сака да има значење. Имав мал херменевтички проблем како да го читам текстот кога Фуко вика „јас сум овде, и ти се смеам" и „не барај да останам ист“. Поради мојата неспособност да "сварам“ такви изјави (најверојатно предизвикана од моето дамнешно платонско уверување дека нашиот ум работи преку воспоставување еднаквост и разлика меѓу нештата) јас се фиксирав на овие изјави и свртев кај коментарите барајќи помош. Не треба многу време да се забележи дека во коментарите за Фуко преовладуваат оние за заборавањето (како вториот вообичаен начин за справувањето со траума).

Основната интуиција која ме водеше беше дека "средбата со смеењето" ('laughing encounter') во она што го нарекуваме „археолошки период“ на делата на Фуко, е колку-толку блиска со "судирот со моќта" во неговите "генеалошки" дела. Во есејот Животот на озлогласените луѓe (The life of Infamous Men), тој го опишува судирот користејќ метафори на „секавица“ и „грмотевица“. Сметам дека овие метафори многу помагаат, бидејќ посочуваат кон разоткривачкиот карактер на оваа средба, ја позиционираат средбата како одредено разоткривање, разјаснување, кое ни укажува на нешто што инаку би останало скриено. Ке се осмелам да речам дека смеењето се однесува на поредокот (археологија), исто како што судирот се однесува на моќта (генеалогија).

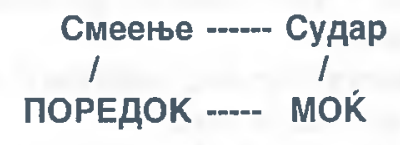

Следната интуиција - донекаде меланхолична беше дека смеењето, кое е „главно привилегија на лудите", може да се гледа како еден вид ветување кое ја по- which are traumatic. I use the word 'freeze' in a manner in which a psychoanalytic author would use it - meaning fixation or/and forgetting - most common ways of dealing with trauma. My first encounter with Foucault was certainly traumatic - a shock disclosed by laughter which I wasn't able to articulate effectively. I couldn't cope with the text's denial to keep identity, with its rejection to have a meaning. I had a simple hermeneutic problem of how I was supposed to read the text when Foucault says 'I am here laughing at you' and 'don't ask me to remain the same'. Due to my incapability to digest such statements (probably caused by my old platonic belief that our mind operates through establishing identity and difference among things) I developed a fixation on these statements and turned to the body of commentaries in search for help. It didn't take much time to realize that in the body of commentaries on Foucault forgetfulness (as the second common way of dealing with trauma) prevaled.

My basic intuition that led me through the way was that the 'laughing encounter' in what we call 'archeological period' of Foucault works is somewhat close to the 'clash with power' in his 'genealogical' writings. In the essay The Life of Infamous Men he describes this clash by using metaphors of 'flash' and 'lighting'. I found these metaphors extremely helpful, for they hint at the revealing quality of this encounter, position this encounter as a certain disclosure, clearing which brings to sight something which would otherwise remain hidden. I dare to suggest that laughter refers to order (archeology) the same way as clash refers to power (genealogy).

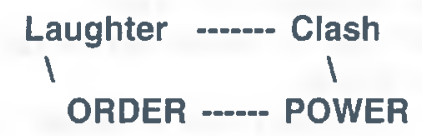

The other intuition - somewhat melancholic - was that one could see laughter which is 'generally the privilege of the insane' as a certain promise hinting at the utopic possibility of 
сочува утописката можност за местото или времето во кое машината на моќта се руши. Во овој вид на фантазија смеењето не е едноставен отпор кон моќта, туку целосно - иако можеби краткотрајно - бегство од самата мрежа моќ-отпор. Колку и да е утописка, оваа фантазија е неопходна и утешителна. А дали овој бескрајно неверојатен момент може да се претвори во постојана и свесна стратегија е сосема друго прашање.

Мојата трета интуиција беше дека ќе се покаже дека смеењето кај Фуко е форма на тероризам - стратегија подоцна прифатена од Делез и Гатари (Deleuze and Guattari); значи смеењето има најмалку три лика: откривање (знаење), утопија (ветување) и тероризам (стратегија). Во текстов ќе се обидам да ги проследам сите три идеи.

Инаку, овој труд е за херменевтика и експериментирање - разработува прашања од типот 1) како едно ископување со значајни резултати било прекинато од мал земјотрес, 2) како да се постапи во овие геолошки околности, 3) како човек да се фрли на земја и да промаши, 4) сево ова и повеќе. Ако бевте доволно внимателни, можевте да забележите дека некои од овие прашања припаѓаат во категоријата на експериментирање, некои се херменевтички, некои не припагаaт никаде, но не грижете се - токму тоа е поентата.

\section{Прва епизода: Мали земјотреси}

„Наваму", рече Мачката, подигајќи ја десната шепа, „живее еден Шапкар: а натаму“, подигајќ ја другата шепа, „живее еден Зајак. Посети кого сакаш: обајцата се луди“.

"Ама јас не сакам да се дружам со луди луѓе", рече Алиса.

"А, тука ништо не се може“, рече Мачката: "Овде сите сме луди. Јас сум луда. И ти си луда." (Луис Керол, Алиса во земјата на чудата)

Пределот на Поредокот на Нештата го тресат мали земјотреси, икања, кои секојпат посочуваат на пукнати- the place or moment where power machine collapses. In this kind of fantasy laughter is not a simple resistance to power but a complete - though maybe only momentary - escape from the power-resistance grid itself. This fantasy, no matter how utopic, is necessary and comforting. Whether this moment of infinite improbability can be turned into a constant and conscious strategy is an entirely different question.

My third intuition was that Foucault's laughter turns out to be a form of terrorism - a strategy which was later adopted by Deleuze and Guattari; so the laughter has at least three faces: revelation (knowledge), utopia (promice) and terrorism (strategy). I will try to unfold all three ideas during the course of the article.

Otherwise, this paper is about hermeneutic and experimentation - it deals with the issues such as 1) how escavation of meaningful responce was interrupted by a little earthquake, 2) how to proceed under these geological circumstances, 3) how to throw yourself on the ground and miss, 4) all mentioned above and many others. If you were careful enough you could see that some of those issues belong to the category of experimentation, some of hermeneutic, some don't belong to any of them, but don't worry - that is precisely the point.

\section{Episode I: Little Earthquakes}

"In that direction," the Cat said, waiving its right paw round, "lives a Hatter: and in that direction," waiving the other paw, "lives a March Hare. Visit either you like: they are both mad."

"But I don't want to go around mad people," Alice remarked.

"Oh, you cannot help that," said the Cat: "We're all mad here. I'm mad. You're mad."

(Lewis Carrol, Alice in Wonderland)

The landscape of the Order of Things is shaken by little earthquakes, hiccups which hint each time at the rupture, a 
ната, на брегот каде една формација исчезнува, оставајќи й место на друга, наеднаш се враќа и потоа пак исчезнува. Ова икање на историјата е парадигматично опишано во воведот на книгата, со најголемата брилјантност за која Фуко е способен. Ова воведно поглавје се издвојува од останатиот дел на книгата, не продолжува во наредните поглавја. Веднаш во следното поглавје, Фуко започнува дискусија за "Лас Менинас", а потоа директно скока кон историското прашање на „класичниот период". Воведот стои настрана, и самиот како книга, имајки одреден интегритет. Обидувајќи се да го лоцира ова поглавје, геометриски, во релација со другите, човек би можел да рече дека тоа постои во метапростор, откривајќ ја самата форма, стратегија и методологија на книгата, шема на искуствата кои човек ги здобива. Јас отсекогаш сум го имала чувството дека сѐ што Фуко сакал да каже во книгата (од гледна точка на методологија, форма, искуство), веќе го има кажано во воведот. Да го погледнеме одблиску.

Уште првиот пасус од Воведот вели: „Оваа книга отпрвин се изроди од еден пасус кај Борхес, од смеењето кое, додека ја читав страната, ги разурнуваше сите познати одредници на мојата мисла - нашата мисла, мисла која го носи печатот на нашата ера и нашата географија кршејки ги сите наредени површини и сите оски со кои сме навикнати да го скротуваме огромното диво мноштво на постоечки нешта..." Ова разурнувачко смеење, опишано низ многуте тектонски метафори, е реакцијата на Фуко на „Кинеска Енциклопедија" (Chinese Encyclopaedia), фантазмагорична класификација на животните, измислена од Борхес. Иако во целост измислена, оваа класификација е способна да произведе чудовишни ефекти врз Фуко кој е изненаден од "острата невозможност тоа да се смисли“. Овој Борхесов пасус ни покажува одреден поредок целосно различен од „сите одредници на нашата мисла“, откривајќ дека поредокот на кој ние сме навикнати и самиот е фиктивен, или уште подобро, откривајки го делењето на измислица и реалност како теоретска фикција, оптичка илузија. Неможноста да се промисли класификацијата резултира од отсуството на заеднички точки, односно унифицираност на класификациите, и тоа му дава на пасусот, coastline where one formation ends giving space to another, returning suddenly and then giving space again. This hiccup of history is paradigmatically described in the introduction to the book, with most brilliance Foucault is capable of. This introductory chapter stands aside from the rest of the book, doesn't unfold in the following chapters. In the very next chapter Foucault starts his discussion of Las Meninas, and after that jumps directly into historical matter of the 'classic period'. Introduction stands aside as a book-in-itself, keeping certain integrity. Trying to locate this chapter geometrically in relation to the following chapters one could say that it exists in a metaspace, revealing the very form, strategy and methodology of the book, scheme of the experience one is going to go through. I always had the feeling that all Foucault wanted to say in the book (from the point of methodology, form, experience) he already said in the introduction. Let us look at it closely.

The very first passage of the Introduction says: 'This book first arose out of a passage in Borges, out of the laughter that shattered, as I read the page, all the familiar landmarks of my thought - our thought, the thought that bears the stamp of our age and our geography - breaking up all the ordered surfaces and all the planes with which we are accustomed to tame the wild profusion of existing things...' The shattering laughter described through the abundance of tectonic metaphors is Foucault's responce to the 'Chinese Encyclopeadia', a fantasmatic classification of animals invented by Borges. Though entirely fictional, this classification is capable of producing monstrous effects on Foucault who is striken by the 'stark impossibility of thinking that'. This passage from Borges presents a certain order totally different from 'all landmarks of our thought" revealing the order we are accustomed to as itself fictional, or better to say revealing the separation between fiction and reality as a theoretical fiction, or optical illusion. The impossibility to think through the classification results from the absence of the common ground, that is, unity of classification, which grants the passage, as Foucault says with 'monstrous quality' or 'absurdity'. We can see here that laughter Foucault experienced is not related to something humorous or funny, but is rather a fright as 
како што вели Фуко, „чудовишен карактер" или „апсурдност". Овде можеме да видиме дека смеењето на Фуко не е поврзано со нешто хумористично ипи смешно, туку е страв како одговор на апорија, бескрајна неверојатност на ум кој би функционирал создавајки такви класификации. Но, овој чудовишен карактер е далеку од тоа да биде бесмислен. Човек може лесно да се справи со бесмислици, оперирајќи преку вообичаените категории на идентитет или разлика (Исто и Друго во Фукоови термини), препознавајќи ги бесмислиците како одвоени (различни) од она што има смисла. Терминот „чудовишност“ овде го сугерира самиот колапс на овие категории, загадувањето на смислата со бесмисленото, откривањето на можноста дека вистината на смислата е бесмислена или барем дека границите на смислата не се баш толку лесни за определување. Читателот се наоѓ на местото на Алиса, која сака да си го зачува разумот, но е свесна за невозможноста за тоа: „А, тука ништо не се може“, рече Мачката: „Овде сите сме луди. Јас сум луда. И ти си луда."

Оваа средба има пародична природа и како и секоја пародија, си игра со сличноста. Кинеската енциклопедија наликува на поредок, всушност и е некој поредок, но таков со кој не можеме да оперираме. Не можеме да ги делиме и групираме нештата според оваа табела, бидејќи тие ни се измолкнуваат и повторно се вракаaт во индиферентност или - сега обратно - создаваат диференцијации каде што не ги очекуваме. Оваа превртена слика на поредок ни покажува дека и поредокот на кој ние сме навикнати, во суштина, е не-ред. Пукнатината која смеењето ја распарчува не е пукнатина во рамките на поредокот, туку пукнатина која ја покажува неоснованоста на самиот поредок. Таа отвора празнина во која нашиот познат поредок "лебди" како неприземјен, бекрајно контингентен, и може да се види како некоја одвоеност, „непознаница“. Празни ната помеѓ „поредоци“ е исто така празнина од поголемо значење - празнина помеѓ „поредокот на нештата" и субјектот способен да го види во неговата контингентност. Не дека некој може по своја желба да напушти еден поредок на нештата, колку за да може другиот да ги промени како прикриени. Напротив, Фуко го потенцира токму ужа- a response to an aporia, infinite improbability of a mind which would operate by producing such classifications. This monstrous quality is far from being just non-sense. One can easily deal with non-sense operating through the usual categories of identity and difference (Same and Other in Foucault's terms), identifying non-sence as separate (different) from sense. The term 'monstrosity' here suggests the collapse of these categories themselves, contamination of sense by non-sense, revealing the possibility that the truth of the sense itself is non-sense or at least that the limits of sense are not that easy to determine. The reader finds herself in the position of Alice willing to keep her sanity but also facing the impossibility of it: "Oh, you cannot help that," said the Cat: "We're all mad here. I'm mad. You're mad."

This encounter has a parodic quality, and as every parody it plays with resemblance. Chinese Encyclopeadia resembles order, in fact is a sort of order, which however we cannot operate with. We cannot divide things and group them according to this table, they slip back into indifference and the other way round - produce differentiations where we would not expect. This inverted image of order shows that the order we are used to in its essence is also a non-order. The rupture in with laughter shatters is not a rupture within the order, but the groundlessness of the order itself. It opens a void in which our familiar order 'hovers' as ungrounded, infinitely contingent, and can be seen in a certain estrangement, 'unfamiliarity'. A void between 'orders' is also a void of greater importance - a void between the 'order of things' and the subject capable of seeing it in its contingency. Not that one can voluntarily leave one order of things for the sake of the other changing them as a disguise. At the opposite, Foucault's puts emphasis precisely on the horror one feels while encountering otherness, complete failure to imagine its possibility. But the positive outcome of this horror is that one is also capable of distancing oneself from one's own familiar order, revealing its axiomatic charac- 
сот што човек го чувствува кога ќе сретне другост, челосниот неуспех да се замисли возможноста на другиот. Но, позитивниот исход од овој ужас е тоа што човек е исто така способен да се дистанцира од сопствениот поредок, откривајќи го аксиоматскиот карактер на истиот поредок кој треба да се прифати, во кој треба да се верува, да се земе како природен за воопшто да постои.

Сметам дека овој Предговор е добро инсцениран експеримент врз читателот, како и повеќето други текстови на Фуко. Верувам дека описите ја играат истата улога како и во Дисциплина и казна - ја отвараат истата празнина, ја создаваат истата далечина. Земете го за пример колежот на Демијан на самиот почеток на $Д$ и $K$ - оваа сцена на мачење не ни е дадена исклучиво за воајеризам, како глетка за презир. Помислете на чувствата на одбивност и препознавање што ги предизвикува кај читателот, и на изненадувањето и стравот. Описот на Демијановата смрт не е способен да побуди смеа како оној пасус кај Борхес, поради нејзината бликост до нас - ние сѐ уште ги сфаќаме премногу сериозно овие делувања на поредок/ моќ преку јавните егзекуции, се препознаваме во тоа, и стравот што човек го чувствува е знак на ова препознавање. Само детален опис доведува до степен на непријатност, што е можен знак на дистанца. Јас би ја искористила метафората на „мали земјотреси“ во врска со употребата на детали во овој опис, споредбено со големиот тектонски потрес во Поредокот на Нештата.

\section{Втора Епизода: Unheimlich, Вознемиреност, Смеа}

Фуко го опишува неговото искуство со смеата употребувајки ги термините непријатност и вознемиреност. "Пасусот на Борхес долго време ме смееше, иако не без одредена непријатност од која не можев да се ослободам" (стр. хvii). Се вели дека следниве три состојби придонесуваат кон непријатност - неможноста да се мисли, зборува и визуелизира (перципира). Сите тие посочуваат на одредена руинираност - руинираност на субјектот на мислите, говорот и перцепцијата. Руинираноста не е само деструк- ter - one that has to be accepted, believed in, be taken as natural in order to exist at all.

I think that this Preface is a well staged experiment on the reader, as well as most of other texts of Foucault. I believe that descriptions play the same role in Discipline and Punish they open the same void, produce the same distance. Take for example the slaughter of Damian in the very beginning of $D \& P$ - this scene of torture is not offered to us for voyeuristic purpose only, as a spectacle for our contempt. Think of both repulsion and recognition it produces in the reader, both surprise and fright. The description of Damian's death is not capable of initiating laughter the way that a passage from Borges does because of its proximity to us - we still take this kind of order/ power operating through public executions too seriously, we recognize ourselves in it, and the fear one feels is the sign of this recognition. Only the detailed description produces a degree of uneasiness which is a possible sign of distance. I would use the metaphor of 'little earthquakes' in relation to the use of detail in this description as compared to a large tectonic rupture in the Order of Things.

\section{Episode II: Unheimlich, Anxiety, Laughter}

Foucault describes his experience of laughter in terms of uneasiness and anxiety. "The passage from Borges kept me laughing a long time, though not without a certain uneasiness that I found hard to shake off." (p. xvii) Three following conditions are said to contribute to this uneasiness - impossibility to think, to speak and to visualize (perceive). All those signify a certain ruination - ruination of the subject of thought, speech, perception. Ruination isn't just a destruction. It can be defined as experience caused by encounter with something which dis- 
ција. Може да се дефинира како искуство предизвикано од средбата со нешто што го вознемирува идентитетот, системот, поредокот. Руинираноста на мислата во Поредокот на Нештата ја предизвикуваат парадокси вгнездени во класификацијата, кои му даваат „чудовишна природа“ на веќе споменатиот пасус. „Централната категорија на животните „вклучени во сегашната класификација", со нејзиното експлицитно упатување кон парадоксите со кои сме запознаени, е индикација дека никогаш нема да успееме да дефинираме стабилна релација на содржан и содржател меѓу секоја од овие категории и онаа која ги вклучува сите..." (xvii)

Руинирањето на мислата е поврзано со неуспехот на имагинацијата, колапсот на геометријата, невозможноста да се визуелизираат, дистрибуираат дадени ентитети во просторот: „...има полош вид на неред од оној на несврзаното, меѓусебното поврзување на непригодни нешта; мислам на нередот во кој фрагментите на голем број можни поредоци светкаат одделно во димензијата, без правило или геометрија, на неправилното... невозможно е да се најде место на живеење за нив, да се дефинира локус под сите нив". Фуко ги нарекува овие невозможни места "хетеротопии“, наспроти „утопии". „Утопиите утешуваат...", вели тој, „Хетеротопиите вознемируваат“ (xviii).

Како се воопшто возможни овие хетеротопии? Фуко го дава одговорот - на местото, или подобро не-местото, на јазикот, бидејќи тука просторот и јазикот се навидум одвоени еден од друг. „Каде на друго место би можеле да се сретнат тие нешта, освен во нематеријалниот звук на гласот кој ги набројува, или на листот кој ја транскрибира нивната листа? Каде на друго место би можеле да бидат поставени едно наспроти друго, освен во не-местото на јазикот?" (xvi)

Меѓутоа, три страници понатаму Фуко ја напушта оваа можност, посочувајќи дека хетеротипиите му нанесуваат штети на јазикот, како и на фантазијата и мислата, дека а-топииите се нужно и а-фазии. turbs identity, system, order. Ruination of thought in the Order of Things is caused by paradoxes imbedded in the classification, which give the passage already mentioned 'monstrous quality'. "The central category of animals 'included in the present classification', with its explicit reference to paradoxes we are familiar with, is an indication that we shall never succeed in defining a stable relation of contained to container between each of these categories and that which includes them all..." (xvii)

Ruination of thought is linked to the failure of imagination, collapse of geometry, impossibility to visualize, distribute given entities in space: "...there is a worse kind of disorder than that of the incongruous, the linking together of things that are inappropriate; I mean the disorder in which fragments of a large number of possible orders glitter separately in the dimension, without law or geometry, of the heteroclite... it is impossible to find a place of residence for them, to define a locus beneath them all." Foucault calls these impossible places 'heterotopias' in opposition to 'utopias'. "Utopias afford consolation...", he says, "Heterotopias are disturbing." (xviii)

How these heterotopias are possible at all, then? Foucault gives his answer - in the place or better non-place of language, for here space and language appear to be separate from each other. 'Where could those things meet, except in the immaterial sound of the voice pronouncing their enumeration, or on the page transcribing it? Where else could they be juxtaposed except in the non-place of language?" (xvi)

However, three pages later Foucault abandones this possibility, pointing that heterotopias damage language as well as imagination and thought, that a-topias are necessarily a-phasias as well. 


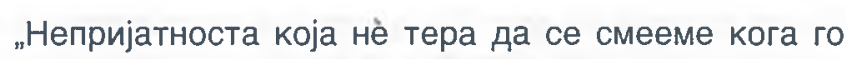
читаме Борхес несомнено е поврзана со длабокото страдање на оние чиј јазик е уништен: загуба на она што е вообичаено за просторот и името" (хіх). Ова страдање е и вознемиреноста на афазичниот кој создава мноштво групации, само за да открие дека тие „повторно се раствораат, бидејќи полето на идентитет кое ги одржува, колку и да е ограничено, е сѐ уште доволно широко за да не биде нестабилно; и така болниот ум продолжува до бесконечноста... конечно тетеравејќи се на работ на вознемиреност" (xviii)

Непријатноста што ја носи смеењето доаѓа од неспособноста на субјектот да го одржи својот идентитет, кој е можен само преку воспоставување на идентитет на дискурсот, идентитет на значењето, на просторот, геометријата на видливото. Одреден елемент на ексцес се појавува на патеката на Фукоовото дело и предизвикува руинирање пред книгата воопшто и да започне - овој чуден однос меѓу поредокот и неговото прекинување, симболичен тоталитет соочен со темелен неред, момент на хаос кој е ставен надвор од репрезентираното. Чарлс Шепардсон (Charles Shepherdson) го смета ова за „еден вид дух, трауматичен елемент, кој ги прогонува делата на Фуко како постојана можност за лудило“ (стр. 21). Тој исто така предлага дека овој елемент, за кој нема место во симболичниот поредок - имено, поради тоа што предизвикува пукнатина во истиот - се манифестира како траума која не може да се интегрира и се открива себеси преку смеење и вознемиреност, а и чудно наликува на нешто што Лакан би го нарекол реалното.

Всушност, ако признаеме дека на првите страни од Поредокот на нештата Фуко се обидува да измисли еден вид јазик, кој овозможува да се зборува за вознемиреноста, тоа ке ни дозволи да го ставиме Фуко во многу поширок контекст од контекстот на неговите сопствени дела. Постои долга традиција на размислување околу вознемиреноста, традиција која најверојатно започнува со Кјеркег (Kierkegaard) и преку Сартр, Хајдегер и Лакан (Sartre, Heidegger, Lacan) оди во доцниот 20-ти век. Можно
"The uneasiness that makes us laugh when we read Borges is certainly related to the profound distress of those whose language has been destroyed: loss of what is common to place and name' (xix) This distress is also the anxiety of the aphasiac who creates a multiplicity of grouping only to find out that they 'dissolve again, for the field of identity that sustains them, however limited it may be, is still wide not to be unstable; and so the sick mind continues to infinity... teetering finally on the brink of anxiety." (xviii)

The uneasiness that laughter provokes, comes from the subject's inability to sustain its own identity, which is possible only through establishing the identity of the discourse, the identity of meaning, space, geometry of the visible. A certain element of excess emerges at the routes of Foucault's work and causes ruination before the book. actually starts - this strange relation between the order and its disruption, symbolic totality confronted by fundamental disorder, moment of chaos that falls outside of representation. Charles Shepherdson refers to it as is 'a certain ghost, traumatic element which haunts Foucault's work as a perpetual possibility of madness itself' (p. 21). He also suggests that this element which has no place in the symbolic order, namely because it causes a rupture in it, manifests itself as a trauma that cannot be integrated and reveals itself through laughter and anxiety, has a strange resemblance to something which Lacan would call the real.

In fact, if we admit that in the first pages of the Order of Things Foucault tries to invent some kind of language which allows to speak about anxiety, it will let us put Foucault in a context much wider than the context of his own works only. There is a long tradition of thinking about anxiety, which probably starts with Kierkegaard and goes through Sartre, Heidegger and Lacan into late XX century. It is possible to interpret Foucault's 'aphasia' in terms of the encounter with the real in the works of Lacan. The question also arises about the possible relation between 
е да се интерпретира Фукоовата „афазија“ во смисла на средбата со реалното во делата на Лакан. Прашањето кое исто така се поставува е за можната врска меѓ Фуко и Хајдегер. Прашањето кое треба да се артикулира е дали она што Фуко го нарекува „пореметување“, „хетеротопија" е истото она кое Хајдегер го нарекува „Битие“, а Лакан „Реалното“.

Сметам дека таквото равенство е мошне привлечно, бидејќи ни дозволува да го сместиме Фуко во традицијата на философијата, нешто што тој самиот го негира, тврдејќи дека не е философ туку едноставно историчар. Исто така, тоа ни допушта да воведеме и онтолошка димензија во неговата мисла. На лример, да речеме дека воведот на Поредокот на нештата ни ја претставува можноста за нешто како Реалното или Битието, нешто што би ја издигнало мислата на Фуко над нивото на историскиот „релативизам" и вознемирувачката контингенција на дискурзивните формации. Ова допушта димензијата на длабочина да се појави (повторно), зад интеракцијата на површината. Меѓутоа, јас сметам дека ова е залудно. Предлагам да се свртиме кон секој од овие мислители и да видиме што имаат тие да кажат на тема вознемиреност.

\section{Хајдегер: Што е метафизика?}

„Што е метафизика?" е прашањето кое Хајдегер го развил на своето инаугурално предавање, откако бил назначен за декан на одделот за филозофија, наследник на неговиот учител Едмунд Хусерл (Edmund Husserl), авторот на "Философијата како строга наука". Во своето предавање, Хајдегер го поставил прашањето на Ништоста како клуч за метафизиката. Тој се труди да ги открие можностите на модусот на "свесност", кој е не-научен и кој, да се надеваме, ḱ ја открие природата на метафизиката.

Различно и од едноставното „отсуство“ на битие и од едноставната негација на битие, ништото не е ефект ниту на негацијата како логичка функција, ниту пак лежи во полето на логичката свесност. Логиката, тврди Хајдегер, самата го претпоствавува ништото како нејзин услов. Фор-
Foucault and Heidegger. The question to be articulated is whether what Foucault calls 'disorder', 'heterotopia' is the same as what Heidegger calls Being or Lacan calls the Real.

I think that such equation is a very tempting enterprise because it allows to position Foucault in the tradition of philosophy, which he himself denied by saying he was not a philosopher but simply a historian. It also allows to introduce an ontological dimension in his thought. Saying for example, that the Preface to The Order of Things introduces a possibility of something like the Real or the Being would elevate Foucault's thought above the level of historical 'relativism' and disturbing contingency of the discursive formations. It allows the dimension of depth to (re-)appear behind the interplay of surfaces. However, I think this attempt is misleading. What I suggest here is to turn to these thinkers themselves and to see what they have to say on the topic on anxiety.

\section{Heidegger: What is Metaphysics?}

"What is metaphysics?" is a question Heidegger developed in his Inaugural Lecture, after he had been appointed to the Chair of Philosophy as a successor of his teacher Edmund Husserl, the author of the 'Philosophy as a Rigorous Science'. In this lecture Heidegger posits the question of Nothingness as a key to methaphysics. He seeks to uncover the possibility of the mode of 'awareness' which is non-scientific and which hopefully would disclose the nature of metaphysics.

Being different both from mere 'absence' of a being and from mere negation of a being, nothing is neither the effect of the negation as a logical function, nor it lies within the field of logical awareness. Logic, Heidegger claims, itself presupposes nothing as its condition. The form of 'negation' remains 'foreign' 
мата на „негацијата“ останува „туѓа“ за ништото и, во обид да го „регистрира“, секогаш доцни. „Ништото веќе се појавува да нѐ пречека."

Оттука, формата во која ништото се открива е „расположение", тип на свесност која не е зависна од интелектуално сфаќање на нешто. Расположението во кое „човекот е донесен пред самото ништо" е „Ангст“ (страв, вознемиреност). Она што го двои Ангстот од стравот е безобјектноста. Оваа не-намерна природа на Ангстот е од посебна важност за Хајдегер, бидејќи индицира дека оној кој е вознемирен, всушност е изгонет отаде тоталитетот на суштествата, изложен на недостаток на бидување на некој начин. Мегуутоа, ништото се сретнува во состојбата на вознемиреност не како нешто изолирано, подалеку од сите нешта на овој свет, туку соединето со нив. Клучната поента која се потенцира е дека во состојбата на вознемиреност, нештата имаат тенденција на испуштање од рака, тонење, а и контролата врз нештата чудно слабее. Појавата на ништото ги менува работите. Односно, да речам, насоката на нештата се менува. Светот како да бега од субјектот. За Dasein, нештата некако веќе не се при рака. Хајдегер тврди дека вознемиреноста ги открива „нештата какви што се“, но секако не како што ги среќаваме во просечната секојдневица. Вознемирениот е изгонет отаде познатата разоткриеност во која суштествата се осмислено манифестии (што значи дека можат да се користат и за нив може да се зборува) во полето на отугеноста. Како во случајот на Фуко, субјектот е соочен со нешто со кое не може да оперира, нешто „непознато“.

Хајдегер експлицитно говори за ова искуство како за "Unheimlichkeit", т.е. искуството на неодомаќинетост во сопственото искуство. „Во Ангст, велиме, постои не-бидување-дома (being-not-at-home)" (во други преводи, „неспокојство" (being ill-at-ease)). Ова не-бидување-дома, не имплицира дека некаде има „дома“, „природно место“ каде што Dasein припаѓa, каде што би било на сигурно од страшната средба со ништото, туку дека оваа Недомност е потребна карактеристика на Dasein и е негова основна припадност. to nothing, and as an attempt to 'register' it, comes always too late. 'The nothing rises to meet us already before that.'

The form in which nothing reveals itself is, therefore, 'mood', a type of awareness which is not dependent of an intellectual grasping of something. The mood in which 'man is brought before nothing itself' is 'Angst' (dread, anxiety). What distinguishes Angst from fear is its objectlessness. This non-intentional character of Angst is of particular importance for Heidegger for it indicates that the one who is anxious is actually driven beyond the totality of beings, exposed to a lack of being in a way. However, nothing is encountered in the state of anxiety not as something isolated, apart from the things in the world, but as one with them. The essential point emphasized is that in the state of anxiety things tend to slide away, sink, that the control over things strangely weakens. The emergence of nothing make things change. Or I would say, the directionality of things changes. The world seems to flee from the subject. The things loose their character of being-ready-at-hand for Dasein. Heidegger claims that anxiety reveals 'things as they are', but certainly not as they are experienced in our average everydayness. The Anxious is driven beyond the familiar disclosedness in which the beings are meaningfully manifest (which means they can be used and spoken of) into the field of estrangement. As in Foucault's case, the subject is confronted with something he cannot operate with, 'unfamiliar'.

Heidegger explicitly refers to this experience as 'Unheimlichkeit', that is, the experience of not being at home in one's own experience. 'In Angst, we say, there is being-not-athome' (in other translation, 'being ill-at-ease'). This being-notat-home, doesn't imply that there is a 'home' somewhere, a 'natural place' where Dasein belongs to, and where it would be free from the scary encounter with nothing, but rather that this Unhomeliness is a necessary characteristic of Dasein and is its essential belonging. 
Исто така, искуството на општа непознатост му е некако „секогаш премногу позната“ на Dasein, бидејќи, како што вели Хајдегер, вознемиреноста - имплицитно - е секогаш присутна. Некој секогаш „се тетерави на работ на ужасот“. Овој философски гест имплицира дека непознатоста на Познатото (нештата го губат своето значење) и познатоста на Непознатото (прастарата природа на вознемиреноста) онтолошки й претходат на познатоста на познатото (разоткриеноста на нештата како да се при рака, како да се референцијални, наредени).

Вознемиреноста или Unheimlichheit за лрв пат го носи Dasein лред суштествата, како такви, оттаму носејќи ја и можноста за метафизика. Донесувајќn ro Dasein лицев-лице со светот во сета негова неоснованост, „расположението" покажува дека иако Dasein задолжително постои во светот, светот не е ниту место на неговата автентичност, ниту негов дом.

\section{Јазикот на Реалното}

Делумно позајмено од Фројдовиот есеј за невообичаеното, делумно од Хајдегеровите предавања за Метафизиката, невообичаеното или Unheimlich станува технички термин во Лакановите списи. Невообичаеното не може да се опише подобро од, едноставно, настан кој предизвикува вознемиреност, да речеме, одредена возбуда, која нема причина, која доаѓ без да и биде времето, како изненадување. Вознемиреноста треба да се разликува од стравот: човек може да се плаши од конкретна личност или објект, стравот треба да е предизвикан од одреден објект, тој има лричина, додека вознемиреноста нема причина. Неа ја предизвикува невообичаеното.

страв - конкретна личност, објект вознемиреност - невообичаеното

Парадигматскиот пример за невообичаеното за кое зборуваат и Фројд и Лакан е двојникот. Важноста на не-
And also, this experience of general unfamiliarity is somehow always-too-familiar for Dasein, for, as Heidegger says, anxiety - implicitly - is always there. One is always 'teetering on the brink of' horror. This philosophical gesture implies that unfamiliarity of the Familiar (things loose their meaning) and familiarity of the Unfamiliar (the primordial character of anxiety) are ontologically prior than familiarity of the familiar (disclosedness of things as being-at-hand, as being referential, orderly).

Anxiety or Unheimlichkeit brings Dasein for the first time before beings as such, therefore brings forth the possibility of metaphysics. Bringing Dasein face-to-face with the world in its groundlessness, the 'mood' shows that though Dasein necessarily exists in the world, the world is not the place of its authenticity, not its home.

\section{The Language of the Real}

Borrowed partially from Freud essay on uncanny, partially from Heidegger's lectures on Metaphysics, uncanny or Unheimlich becomes a technical term in Lacan's writings. Uncanny cannot be described better as simply an anxiety provoking event, let's say, a certain excitement, which has no reason, comes without being due, as a surprise. Anxiety should be distinguished from fear: one can be afraid of a concrete person or object; fear should be provoked by an object, it has a cause, while anxiety doesn't have a cause. It is provoked by uncanny.

fear - concrete person, object anxiety - uncanny

The paradigmatic example of the uncanny to which both Freud and Lacan refer is the double. The importance of un- 
вообичаените феномени е дека тие се портата кон реалното. Вознемиреноста, резултат на средбата со невообичаеното, е сигнал/симптом дека човек се приближува до реалното.

Во контраст со претходните психоаналитичарски автори кои ја сфаќаа вознемиреноста, едноставно, како една лоша работа, нешто што треба да се отстрани, Лакан, во хајдегеријански стил, признава дека вознемиреноста има позитивен квалитет, токму зашто го приближува субјектот во допир со реалното. Реалното е она нешто што недостига во симболичниот поредок, нешто што не може да биде регистрирано во него, нешто до што може да се приближиме, но никогаш не можеме да го сфатиме. Реалното создава таканаречени „дупки“ во рамките на симболичкото кои ја покажуваат нецелосноста на симболичката структура. Реалното прилаѓа надвор од операциите на знаењето и логиката на претставување.

На некој начин, знејќи дека сите три споменати автори пробуваат да направат јазик со кој ќе можат да зборуваат за вознемиреноста, тие доагаaт, помалку или повеќe, до исти резултати. Сите тројца

1) ја опишуваат средбата која предизвикува вознемирување како екцесивна, без причина, изненадување, шок;

2) зборуваат за колапсот на јазикот/неуспехот на значењето

3) зборуваат за средбата со извесен прекин, или низа прекини, и

4) сугерираат руинирање на репрезенционалната логика; субјектот не може да се оддели од расположението, загаден е или вовлечен во него.

Meѓyтоа, и покрај сите сличности меѓу трите фигури, мислам дека Хајдегер и Лакан имаат повеќе заеднички точки меѓу себе, отколку со Фуко. Најголемата разлика која ја гледам лежи во интерлретацијата на значењето на вознемиреноста. Кај Хајдегер и Лакан функцијата е „откривачка“. Ангстот ги открива суштествата како canny phenomena is that they are the gate to the real. Anxiety, caused by one's encounter with uncanny, is a signal/symptom of one's getting close to the real.

In contrast with earlier psychoanalytical authors that perceived anxiety as being simply a bad thing, something to get rid of, Lacan, more in a Heideggerian manner, admits that anxiety has positive quality, precisely because it brings the subject in touch with the real. Real is something lacking in the symbolic order, something that cannot be registered in it, can be approached, but never grasped. Real creates so called 'holes' within the symbolic which show incompleteness of the symbolic structure. Real falls outside the operations of knowledge and the logic of representation.

In a way, given that all three mentioned authors try to develop a language in order to speak of anxiety, they approach more or less the same results. All three of them

1) describe the anxiety provoking encounter as excessive, not having a cause, a surprise, shock;

2) speak about the collapse of language/failure of the signifier;

3) speak of the encounter as a certain rupture, or a chain of ruptures;

4) suggest the ruination of representational logic the subject is unable to separate himself from the 'mood', is contaminated or absorbed by it.

However, in spite of all similarities among three figures, I think that Heidegger and Lacan have more in common with each other than with Foucault. The major difference that I see lies in the interpretation of the meaning of anxiety. In Heidegger and Lacan the function of anxiety is 'revealing'. Angst reveals beings as beings in the black light of nothing, bringing forth the 
суштества во црното светло на ништото, создавајќи можност за метаморфоза. За Лакан, вознемиреноста го разоткрива реалното како невозможната граница на симболичниот поредок, а последниов го открива како секогаш прекинат и некомплетен. Смеењето кај Фуко го открива постоењето на поредокот, но во исто време отвора и можност за експериментирање. Смеењето го доведува субјектот до руинирање, што всушност доведува до можноста за реновирање. Функцијата на смеењето ја индицира можноста за едно движење на експериментирање.

\section{Трета Епизода: Како да се фрлиш наземи} и да промашиш.

Автостоперскиот водич низ галаксијата има да го каже ова за летањето.

Постои уметност на, или подобро, финта за летањето. Финтата е да се научи како да се фрлиш наземи и да промашиш.

Одбери убав ден, вели водичот, и пробај.

Првиот дел е лесен. Сѐ што треба е способност да се фрлиш нанапред со сета тежина и спремност да не ти пречи дека ќе боли.

Всушност, ќе боли ако не успееш да ја промашиш земјата.

(Автостоперската трилогија)

Парадоксално, знам, но спремна сум да тврдам дека лоентата на Фуко е донекаде слична на предлогот од Автостоперската трилогија: тој ја предлага возможноста човек да се фрли наземи и да промаши. Само што земјата значи нешто друго - значи поредок. Посочувањето на бестемелноста на лоредокот на некој начин значи лебдење над него, бидејќи поредокот е темел. Но, за да лебди, субјектот мора да ја предаде својата волја, за да биде способен да оперира, мора да изгуби одреден степен на „нормалност“ и да биде способен да го издржи шокот на не-идентитетот.

„Не, не, јас не сум таму каде што лежиш, чекајќи ме, туку ете таму, и ти се смеам... Не прашувај кој сум и possibility of metaphysics. For Lacan anxiety discloses the real as the impossible limit of the symbolic order, reveals the latter as always disrupted and incomplete. Laughter in Foucault reveals the existence of the order, but at the same time it opens a possibility for experimentation. Laughter brings subject to ruination which in fact leads to a possibility of renovation. The function of laughter indicates the possibility of the movement of experimentation.

\section{Episode III: How to throw yourself on the ground and miss.}

The Hitchhiker's Guide to the Galaxy has this to say on the subject of flying.

There is an art, or, rather, a knack to flying. The knack lies in learning how to through yourself on the ground and miss.

Pick a nice day, it suggests, and try it.

The first part is easy. All it requires is simply the ability to throw yourself forward with all your weight, and the willingness not to mind that its going to hurt.

That is, it's going to hurt if you fail to miss the ground.

\section{(Hitchhiker's Trilogy)}

Paradoxically enough, I am willing to claim that Foucault's point is somewhat similar to the suggestions from Hitchhiker's Trilogy. he suggests the possibility of throwing oneself on the ground and miss. Only the ground means something different it means the order. Showing the groundlessness of the order means in a way hovering above it, for the order is a ground. But for the sake of this hovering the subject has to give up his will, to be able to operate, has to loose a certain degree of 'sanity' and has to be able to sustain the shock of non-identity.

"No, no, I'm not where you are lying in wait for me, but over there, laughing at you... Don't ask me who I am and don't 
не барај да останам ист: прелушти им на твоите бирократи и нашата полиција да ни ги проверат документите. Барем поштеди нѐ од нивниот морал кога пишуваме." (Археологија на знаењето)

Во овој пасус смеењето повторно влегува во игра, но неговата функција е различна. Повеќе не е слично на фигурите на онтолошката мисла, како Реално или Битие, не предлага лрекин во дискурсот, неуспех да означи, колапс, туку се открива себе како свесна стратегија. Оваа стратегија е поврзана со нешто што Фуко го нарекува фикција, и е важен концепт во Поредокот на Нештата, како и во Археологија на Знаењето. Бидејќи елизодата со Кинеската Енциклопедија покажа дека секој поредок е фиктивен, и дека самата дистинкција меѓу фикција и реалност е еден вид на илузија или и самата е фикција, поимот "фикција“ отвора бесконечен простор за експериментирање. Фикцијата или „пишувањето“, Фуко ги смета за простор слободен од законот на задолжителен идентитет, хетеротопија каде што субјектот може да експериментира со промената или метаморфозата - да стане мува, полжав, чудовиште. Она што Фуко како да го предлага овде е еден вид на тероризам преку пишување - каде што непријателот на поредокот ги менува местата и маските и станува невидлив и бега во моментот кога некој ќе се обиде да го фати. Гуштер. Овој тероризам може да се лојави во различни форми: освен метаморфозата - стратегија подоцна усвоена од Делез и Гатари (види „Како да се престориш во тело без органи" - Фуко користи уште една стратегија: прави читателот и самиот текст да дојдат лице в лице со неговата контингентност, каде ја доведува во прашање неговата способност да има значење и каде што значењето колабира во смеење. Овој тип на субјективност, кој не е поврзан со идентитетот и е произведен екслериментално во не-просторот на пишувањето, е способен да ја „промаши земјата" и да лебди некаде помеѓу. Иако Фуко го елаборираше концептот на субјективност и субјективизација (како само-продукција заедно со потчинетост) многу подоцна, траги на концептот може да се видат уште во археолошкиот период, или, во најмала рака, постои интуиција дека „борбата за објективност се претставува себеси ask me to remain the same: leave it to your bureaucrats and our police to see that our papers are in order. At least spare us their morality when we write." (Archeology of Knowledge)

In this passage laughter comes into play again, but the function of it is different. It no longer bares resemblance with the figures of ontological thought, such as Real or Being, doesn't suggest a rupture in discourse, failure to signify, collapse, but rather reveals itself as a conscious strategy. This strategy is connected with something Foucault calls fiction, which is an important concept in The Order of Things as well as in the Archeology of Knowledge. Since the episode with Chinese Encyclopaedia implied that every order is fictional, and that the very distinction between fiction and reality is a kind of illusion or fiction itself, the notion of 'fiction' opens infinite space for experimentation. Fiction or 'writing' is perceived by Foucault as a space free from the law of compulsory identity, a heterotopia where subject can experiment with the change or metamorphosis - become a fly, become a snail, become a monster. What Foucault seems to suggest here is a form of terrorism through writing - where the enemy of the order changes places and masks and becomes invisible and flees at the moment one tries to catch him. A lizard. This terrorism can take different forms: apart from the metamorphosis - the strategy later adopted by Deleuze and Guattari (see 'How One Make Oneself a Body Without Organs'), Foucault also uses another strategy: making the reader and the text itself come face to face with its own contingency, where he puts into question its own capacity to bare a meaning, where meaning collapses in laughter. This type of subjectivity, that is not linked to identity and is experimentally produced in the non-space of writing, is capable of 'missing the ground' and hovering in-between. Though Foucault elaborated the concept of subjectivity and subjectivation (as self-production along with subjection) much later, one can see the trace of the concept already in the archeological period, or at least there is an intuition that "the struggle for subjectivity presents itself as the right to difference, variation and metamorphosis" (Deleuze, p. 106). 
како право на разлика, варијација и метаморфоза." (Deleuze, p. 106)

\section{БИБЛИОГРАФИЈА}

Adams, Douglas, Hitchhiker's Trilogy, NY, 1983

Carroll, Lewis, Alice's Adventures in Wonderland \& Through the Looking-Glass, Signet Classic, 1978

Deleuze, Foucault, University of Minnessota, 1998

Foucault, The Order of Things, NY, 1990

Foucault, Archeology of Knowledge, NY, 1974

Heidegger, Basic Writings, NY, 1995

Lacan, The Four Fundamental Concepts of Psychoanalysis, NY, 1998 Shepherdson, Charles, History and the Real: Foucault with Lacan, Postmodern Culture v. 5 n. 2 (January, 1995)

Trauma, Explorations in Memory, ed. by Cathy Caruth, John Hopkins

University Press, 1995

\section{BIBLIOGRAPHY}

Adams, Douglas, Hitchhiker's Trilogy, NY, 1983

Carroll, Lewis, Alice's Adventures in Wonderland \& Through the Looking-Glass, Signet Classic, 1978

Deleuze, Foucault, University of Minnessota, 1998

Foucault, The Order of Things, NY, 1990

Foucault, Archeology of Knowledge, NY, 1974

Heidegger, Basic Writings, NY, 1995

Lacan, The Four Fundamental Concepts of Psychoanalysis, NY, 1998 Shepherdson, Charles, History and the Real: Foucault with Lacan, Postmodern Culture v. 5 n. 2 (January, 1995)

Trauma, Explorations in Memory, ed by Cathy Caruth, John Hopkins University Press, 1995 